УДК 657

Камінська I.М., к.е.н., доцент

Дорош В.Ю., к.е.н., доцент

Ковальчук А.Ю., бакалавр

Луцький національний технічний університет

\title{
АКТИВИ ПІДПРИЄМСТВА: МОРФОЛОГІЧНИЙ АНАЛІЗ КАТЕГОРІЇ, СКЛАД ТА КЛАСИФІКАЦІЯ
}

\author{
У статті розглянуто сучасні підходи науковців до трактування категорії «активи підприємства» на основі чого \\ вдосконалено їх розуміння. Визначено склад, основні ознаки та властивості активів підприємства. Систематизовано \\ основні критерії класифікації активів підприємства. \\ Ключові слова: активи підприємства, майно підприємства, ресурси підприємства, пасиви підприємства.
}

Kaminska I., Dorosh V., Kovalchuk A.

\section{ASSETS OF AN ENTERPRISE: MORPHOLOGICAL ANALYSIS OF CATEGORY, COMPOSITION AND CLASSIFICATION}

The modern approaches of scientists to the interpretation of the category of «assets of an enterprise» are investigated on the basis of which their understanding is improved. The composition, main features and properties of the assets of an enterprise are determined. The main criteria for classification of enterprise assets are systematized.

Keywords: assets of an enterprise, property of the enterprise, resources of the enterprise, liabilities of the enterprise.

Каминская И.Н., Дорош В.Ю., Ковальчук А.Ю.

\section{АКТИВЫ ПРЕДПРИЯТИЯ: МОРФОЛОГИЧЕСКИЙ АНАЛИЗ КАТЕГОРИИ, СОСТАВ И КЛАССИФИКАЦИЯ}

\begin{abstract}
В статье рассмотрены современные подходы ученых к трактовке категории «активы предприятия» на основе чего улучшено их понимание. Определен состав, основные признаки и свойства активов предприятия. Систематизированы основные критерии классификации активов предприятия.

Ключевые слова: активы предприятия, имущество предприятия, ресурсы предприятия, пассивы предприятия.
\end{abstract}

Постановка проблеми у загальному вигляді i iї зв'язок 3 важливими науковими та практичними завданнями. Матеріальною основою здійснення господарської діяльності кожного підприємства є активи [1, с. 17; 2, с. 357], що безпосередньо й опосередковано беруть участь у створенні кінцевого продукту. Саме їх наявність уможливлює функціонування i розвиток підприємства, безперервність i збалансованість виробничо-господарської діяльності, фінансовий стан суб'єкта господарювання, рівень його конкурентоспроможності та інвестиційної привабливості нині i в майбутньому. Вказане визначає потребу обгрунтування, насамперед, теоретичних засад функціонування активів підприємства.

Аналіз останніх досліджень, у яких започатковано вирішення проблеми. Дослідженню питань формування і використання активів підприємства, управління ними присвятило свої публікації безліч відомих іноземних і вітчизняних учених, зокрема, Авраменко О.В., Бланк І.А., Білик М.Д., Бутинець Ф.Ф., Горячева К.С., Срмошенко М.М., Ілляшенко С.М., Ковальов В.В., Коробов М.Я., Мамонтова Н.А., Мендрул О.Г., Мних Є.В., Мойсеєнко І.П., Поддєрьогін А.М., Покропивний С.Ф., Пушкар М.С., Рєпіна I.М., Скоробогатова В.В., Турило А.М., Шеремет А.Д. та багато інших. Однак, не зважаючи на істотний внесок науковців у розвиток даної тематики, а також на те, що активи підприємства є однією з найважливіших категорій економіки підприємства, іiі теоретичні аспекти не в повній мірі досліджені науковцями [3, с. 552]. Вчені доволі фрагментарно висвітлюють концептуальні й методичні засади функціонування і розвитку активів підприємства, осмислення їх змісту не $є$ цілковитим i однозначним, прикладні питання підвищення ефективності використання таких 
ресурсів теж недостатньо опрацьовані і без урахування сучасних умов ведення й розвитку бізнесу. Треба зауважити, що науковці здебільшого зосереджують увагу на окремих складових елементах активів підприємства та недостатньо активно досліджують їх в цілому й комплексно. Це обумовлює потребу подальших наукових обгрунтувань даної проблематики.

Цілі статті. Основні цілі статті полягають в подальшому комплексному i системному розвитку знань про сутність, особливості та різновиди активів підприємства.

Виклад основного матеріалу дослідження 3 повним обгрунтуванням отриманих наукових результатів. Очевидно, що вихідною умовою ефективного ведення наукового дослідження $є$ з'ясування понятійного апарату, адже саме це забезпечує єдиний підхід до трактування категорій та дозволяє виокремити ознаки, які характерні для певного об'єкта [4, с. 338]. Категорія «активи» є надзвичайно важливою категорією у обліковому, фінансовому, управлінському, правовому та інших аспектах економічної роботи будь-якого підприємства [5]. Дана категорія походить із теорії бухгалтерського обліку, і пов'язана з побудовою бухгалтерського балансу суб'єкта господарювання [6]. У перекладі $з$ латинської «actives» означає діючий, діяльний.

В науковій економічній та фінансовій літературі існують різні підходи вчених до трактування категорії «активи підприємства» (табл. 1), що певним чином різняться та $€$ дещо суперечливими.

Таблиця 1.

Морфологічний аналіз категорії «активи підприємства»

\begin{tabular}{|c|c|c|}
\hline Автор(и) & Трактування категорії & Ключовий підхід \\
\hline 1 & 2 & 3 \\
\hline \multicolumn{3}{|c|}{ Як об'єкт власності } \\
\hline $\begin{array}{l}\text { Сердюков К.Г., } \\
\text { Андруха К.С. }\end{array}$ & $\begin{array}{l}\text { Активи підприємства - це ресурси, що були сформовані під час створення } \\
\text { суб'єкта господарювання й надходять на підприємство за результатами } \\
\text { господарської діяльності, перебувають у розпорядженні підприємства та } \\
\text { збільшують економічні вигоди у маибутньому [7]. }\end{array}$ & $\begin{array}{c}\text { Ресурси, що були } \\
\text { сформовані під час } \\
\text { створення } \\
\text { підприємства. }\end{array}$ \\
\hline $\begin{array}{l}\text { Поліщук М.П., } \\
\text { Михайленко } \\
\text { П.П. } \\
\end{array}$ & $\begin{array}{l}\text { Активи - ресурси, контрольовані підприємством в результаті минулих } \\
\text { подій, використання яких, як очікується, приведе до отримання економічних } \\
\text { вигод у майбутньому [8]. }\end{array}$ & \multirow[t]{3}{*}{$\begin{array}{c}\text { Ресурси, } \\
\text { контрольовані } \\
\text { підприємством. }\end{array}$} \\
\hline $\begin{array}{l}\text { Панасовський } \\
\text { Ю.В. та ін. }\end{array}$ & $\begin{array}{l}\text { Активи - ресурси, які контрольовані підприємством в результаті минулих } \\
\text { подій і від яких очікуються деякі економічні вигоди для суб'єкта } \\
\text { господарювання в майбутньому [9, с. } 28] .\end{array}$ & \\
\hline Олійник Т.О. & \begin{tabular}{|l} 
Активи підприємства - це контрольовані підприємством ресурси, \\
використання яких зумовлює збільшення економічних ефектів $[10$, с. 76].
\end{tabular} & \\
\hline Ковал & $\begin{array}{l}\text { Активи підприємства - це ресурси, які перебувають у розпорядженні } \\
\text { підприємства і, використання яких веде до збільшення економічних вигід у } \\
\text { маибутньому [11, с. 197]. }\end{array}$ & $\begin{array}{l}\text { Ресурси наявні у } \\
\text { розпорядженні } \\
\text { підприємства. }\end{array}$ \\
\hline Рєпіна I.M. & $\begin{array}{l}\text { Активи підприємства - це варіативна частина його ресурсів, яка обирається } \\
\text { суб'єктом господарювання для здійснення підприємницької діяльності за } \\
\text { схваленої бізнес-моделі через свою здатність, з урахуванням фактору часу } \\
\text { та ризику, приносити економічну вигоду та забезпечувати } \\
\text { конкурентоспроможність підприємства на конкретному ринку [3, с. 552]. }\end{array}$ & $\begin{array}{l}\text { Варіативна частина } \\
\text { ресурсів } \\
\text { підприємства. }\end{array}$ \\
\hline Бланк I.O. & $\begin{array}{l}\text { Активи підприємства - це контрольовані ним економічні ресурси, } \\
\text { сформовані за рахунок інвестованого в них капіталу, які характеризуються } \\
\text { детермінованою вартістю, продуктивністю і здатністю генерувати дохід, } \\
\text { постійний оборот яких у процесі використання пов'язаний з чинником часу, } \\
\text { ризику та ліквідності [12, с. 19-20]. }\end{array}$ & \multirow[t]{2}{*}{$\begin{array}{l}\text { Ресурси, сформовані } \\
\text { за рахунок } \\
\text { інвестованого в них } \\
\text { капіталу. }\end{array}$} \\
\hline Іванчук Н.В. & $\begin{array}{l}\text { Активи підприємства - це ресурси, сформовані за рахунок інвестованого в } \\
\text { них капіталу, контрольовані підприємством внаслідок минулих подій, які } \\
\text { характеризуються детермінованою вартістю, продуктивністю і здатністю } \\
\text { генерувати дохід, постійний оборот яких у процесі використання пов’язании } \\
3 \text { чинником часу, ризику й ліквідності та призведе до отримання } \\
\text { економічних вигод у маибутньому [13, с. } 110] \text {. }\end{array}$ & \\
\hline Лисевич С.Г. & $\begin{array}{l}\text { Активи - це економічні ресурси, що використовуються у господарській } \\
\text { діяльності підприємства з метою отримання прибутку [14]. }\end{array}$ & $\begin{array}{l}\text { Економічні ресурси } \\
\text { підприємства. }\end{array}$ \\
\hline Чернецька С.А. & $\begin{array}{c}\text { Активи - це ресурси, використання яких має в маибутньому призвести до } \\
\text { отримання прибутку [15]. }\end{array}$ & $\begin{array}{c}\text { Ресурси } \\
\text { підприємства. }\end{array}$ \\
\hline Петруня Н.В. & $\begin{array}{c}\text { Активи підприємства } є \text { тими ресурсами, які повинні забезпечити ефективне } \\
\text { функціонування підприємства ... [5, с. } 121] .\end{array}$ & $\begin{array}{c}\text { Ресурси } \\
\text { підприємства. }\end{array}$ \\
\hline
\end{tabular}




\begin{tabular}{|c|c|c|}
\hline & & родовж.. \\
\hline 1 & 2 & 3 \\
\hline \multicolumn{3}{|c|}{ Як об'єкт управління } \\
\hline Шелудько В.М. & $\begin{array}{c}\text { Активи підприємства - це майно в його матеріальній і нематеріальній } \\
\text { формах, придбане підприємством за рахунок власних або залучених } \\
\text { ресурсів, що перебувають у його розпорядженні та призначені для } \\
\text { використання у фінансово-господарській діяльності з метою отримання } \\
\text { прибутку [16]. }\end{array}$ & $\begin{array}{l}\text { Майно підприємства в } \\
\text { його матеріальній і } \\
\text { нематеріальній } \\
\text { формах. }\end{array}$ \\
\hline Стоянова О.Г. & $\begin{array}{l}\text { Активи підприємства - це майно, в його матеріальній і нематеріальній } \\
\text { формах, придбане підприємством за рахунок власних або залучених } \\
\text { ресурсів, що перебувають у його розпорядженні та призначені для } \\
\text { використання у фінансово-господарскій діяльності } 3 \text { метою отримання } \\
\text { прибутку [17, с. 12]. }\end{array}$ & \multirow[t]{2}{*}{$\begin{array}{l}\text { Майно, в його } \\
\text { матеріальній і } \\
\text { нематеріальній } \\
\text { формах. }\end{array}$} \\
\hline Константюк Н. & $\begin{array}{l}\text { Активи підприємства - це майо в його матеріальній і нематеріальній } \\
\text { формах, придбане підприємством за рахунок власних або залучених } \\
\text { ресурсів, що перебувають у його розпорядженні та призначені для } \\
\text { використання у фінансово-господарській діяльності } 3 \text { метою отримання } \\
\text { прибутку [18]. }\end{array}$ & \\
\hline Соколов Я.В. & $\begin{array}{l}\text { Актив - це все майно, яке відображено в інвентаризаційному описі, тобто } \\
\text { актив розуміється як: майно, що перебуває у власності підприємства [19, с. } \\
226-231] \text {. }\end{array}$ & $\begin{array}{l}\text { Майно відображене в } \\
\text { інвентаризаційному } \\
\text { описі. }\end{array}$ \\
\hline \multicolumn{3}{|c|}{ Як об'єкт інвестування } \\
\hline Мних Є.В. & $\begin{array}{l}\text { Активи підприємства - це засоби суб’єкта господарювання, які потрібні для } \\
\text { його функціонування у різних формах діяльності } 3 \text { метою одержання } \\
\text { прибутку [20]. }\end{array}$ & $\begin{array}{l}\text { Засоби суб'єкта } \\
\text { господарювання. }\end{array}$ \\
\hline Колодяжна К.С. & $\begin{array}{l}\text { Активи підприємства - це господарські засоби, сформовані за рахунок } \\
\text { власного і позикового капіталу, що характеризуються продуктивністю і } \\
\text { здатністю генерувати дохід внаслідок постійного обороту [21, с. 91-93]. }\end{array}$ & \multirow{2}{*}{$\begin{array}{l}\text { Господарські засоби, } \\
\text { сформовані за } \\
\text { рахунок власного і } \\
\text { позикового капіталу. }\end{array}$} \\
\hline $\begin{array}{l}\text { Каціман C.O., } \\
\text { Шаманська O.I. }\end{array}$ & $\begin{array}{l}\text { Активи підприємства являють собою господарські засоби, сформовані за } \\
\text { рахунок власного і позикового капіталу [2, с. 357]. }\end{array}$ & \\
\hline \multicolumn{3}{|c|}{ Як иінність } \\
\hline $\begin{array}{l}\text { Скоробогатова } \\
\text { В.В. }\end{array}$ & $\begin{array}{l}\text { Активи - це сукупність матеріальних і нематеріальних цінностей } \\
\text { підприємства, які мають грошову оцінку, а також вартостей, у вигляді зносу, } \\
\text { резерву, гудвілу тощо, формування та використання яких призведе до } \\
\text { отримання економічних вигод у маиббутньому [4, с. 347]. }\end{array}$ & $\begin{array}{c}\text { Сукупність } \\
\text { матеріальних і } \\
\text { нематеріальних } \\
\text { цінностей } \\
\text { підприємства. } \\
\end{array}$ \\
\hline \multicolumn{3}{|c|}{ Як об'єкт обліку } \\
\hline $\begin{array}{l}\text { Ковалев В.В., } \\
\text { Патров В.В. }\end{array}$ & $\begin{array}{l}\text { Активи - величина витрат підприємства, яка утворилася в результаті } \\
\text { попередніх операцій та фінансових угод, і понесених ним витрат заради } \\
\text { можливих маибутніх доходів [22]. }\end{array}$ & $\begin{array}{l}\text { Величина витрат } \\
\text { підприємства. }\end{array}$ \\
\hline
\end{tabular}

Багато вчених, трактують категорію «активи підприємства», базуючись на положеннях бухгалтерського обліку. Зокрема, у Національному Положенні бухгалтерського обліку наведено визначення активів, під якими розуміються ресурси, що контролюються підприємством в результаті минулих подій, використання яких, як очікується, приведе до надходження економічних вигод у маибуунььму [23; 24].

Як зауважує, Скоробогатова В.В., національні стандарти бухгалтерського обліку акцентують увагу на наявності двох основних умов [4, с. 338]:

1) суб'єкти господарювання повинні мати право власності на активи;

2) можливість отримання економічних вигід від їх використання в маибутньому.

Також науковці, визначаючи зміст активів підприємства, розглядають їх як об'єкт власності, об'єкт обліку, об’єкт управління, об'єкт інвестування.

Аспекти категорії «активи» часто ототожнюються 3 такими категоріями як «фінансові ресурси», «виробничі засоби» і, навіть, «капітал» [5].

Підходи науковців до трактування сутності категорії «активи підприємства» можна згрупувати у три групи відповідно до яких вони розглядаються як:

- ресурси, що наявні в підприємства. Проте, в економічній практиці виокремлюють земельні, трудові, матеріальні, нематеріальні і фінансові ресурси, а активи охоплюють лише матеріальні, нематеріальні і фінансові ресурси;

- майно підприємства в матеріальній і нематеріальній формах. Проте, все, що знаходиться в активі, згідно Плану рахунків бухгалтерського обліку, не можна називати майном, або тими ж матеріальними цінностями, оскільки грошові кошти, гудвіл, резерв 
сумнівних боргів до цих категорії відносити не доцільно [4, с. 343];

- господарські засоби, що забезпечують підприємству прибуток. Проте, такий підхід доволі загальний, адже не лише господарські засоби спроможні забезпечувати економічні вигоди суб'єкту господарювання.

Скоробогатова В.В., узагальнюючи результати аналізу категоріі «актив» в довідковій літературі, які представлені у таблиці 2, робить висновки, що на сьогодні можна визначити та відокремити основні категорії, які характеризують теоретичні підходи до визначення сутності даної категорії.

Таблиця 2. Узагальнення результатів аналізу облікової категорії «актив» у довідковій літературі [4, c. 342]

\begin{tabular}{|c|c|c|}
\hline Тлумачення & Кількість & ПІБ автора \\
\hline $\begin{array}{c}\text { Ліва частина } \\
\text { балансу }\end{array}$ & 19 & $\begin{array}{c}\text { Агєєва Ю.Б., Азріліян А.Н., Арінушкін М.С., Бабаєв Ю.А., Бабенко } \\
\text { І.П., Бакаев А.С., Бічік С.В., Бойко В.М, Борісов А.Б., Бутинець Ф.Ф., } \\
\text { Голощапов Н.А., Ермошенко Н.Н., Загородній А.Г., Конопліцький } \\
\text { В.А., Красій С.А., Копоруліна В.Н., Мороз А.М., Науменко В.І., } \\
\text { Гарбузов В.Ф. }\end{array}$ \\
\hline Сукупність майна & 7 & $\begin{array}{c}\text { Бакаев А.С., Бернар I., Борісов А.Б., Науменко В.І., Мочерний С.В., } \\
\text { Загородній А.Г., Конопліцький В.А. }\end{array}$ \\
\hline Ресурси & 5 & $\begin{array}{c}\text { Бутинець Ф.Ф. Галяпін Л.В., Редько А.Ю., Велш Глен А., Сазерленд } \\
\text { Дж., Кэнуэлл Д. }\end{array}$ \\
\hline Власність & 6 & $\begin{array}{c}\text { Агєєва Ю.Б., Азрилиян А.Н., Бабенко І.П., Новіков В.А., Рай Энтони, } \\
\text { Шемшученко Ю.С. }\end{array}$ \\
\hline $\begin{array}{c}\text { Перевищення сум } \\
\text { доходу фірми над } \\
\text { ії̈ витратами }\end{array}$ & 5 & Бічік С.В., Бойко В.М., Азріліян А.Н., Борісов А.Б., Ермошенко Н.Н. \\
\hline Вартість & 2 & Бічік С.В. Ожегов C.I. \\
\hline $\begin{array}{l}\text { Господарські } \\
\text { засоби }\end{array}$ & 2 & Арінушкін М.С., Бакаєв А.С. \\
\hline $\begin{array}{l}\text { Економічні } \\
\text { ресурси }\end{array}$ & 2 & Бланк І.О., Саблук П.Т. \\
\hline $\begin{array}{l}\text { Наявні кошти } \\
\text { фірми }\end{array}$ & 1 & Корнієнко Г.В. \\
\hline $\begin{array}{l}\text { Матеріальні } \\
\text { цінності }\end{array}$ & 1 & Фамінський І.П. \\
\hline
\end{tabular}

На основі проведеного теоретичного аналізу сутності категорії «активи» в економічній літературі й нормативно-правових актах, узагальнюючи та систематизуючи підходи вчених, на нашу думку, активи доцільно розглядати як сукупність матеріальних $i$ нематеріальних цінностеи підприємства у вартісному виразі, щзо формуються 3 власних $i$ позичкових джерел фінансування, систематично поновлюються (відновлюються), обслуговуючи виробничо-господарськии прочес $i$ забезпечуючи иого безперервність задля досягнення економічних і соиіальних вигід.

Активи підприємства характеризуються балансовою вартістю, продуктивністю і здатністю генерувати дохід унаслідок постійного обороту [2, с. 357].

Окрім того активам підприємства притаманні такі властивості [3, с. 552]:

-результатоорієнтовність;

-динамічність;

-нематеріаломісткість.

Серед основних ознак активів підприємства науковці виокремлюють наступні (на основі [4, с. 342]):

- активи є матеріальними і нематеріальними об'єктами, що перебувають у користуванні і під контролем власників підприємства;

- наявність активів забезпечує безперервний процес виробництва;

- активи $є$ основою отримання економічних вигід у результаті їх використання;

- активи здатні взаємо замінюватись, конвертуватись і реструктуруватись;

- активи формуються у результаті минулих подій. 
Формуючи активи підприємства, варто значну увагу приділити вибору оптимального їх рівня і раціональної структури, враховуючи специфіку діяльності кожного підприємства та вплив факторів зовнішнього та внутрішнього середовища.

До них належать усі матеріальні цінності, нематеріальні активи та кошти, що належать суб'єкту господарювання на певну дату, їх розміщення та використання [25, с. 439]. На рисунку 1 зображено склад активів підприємства.

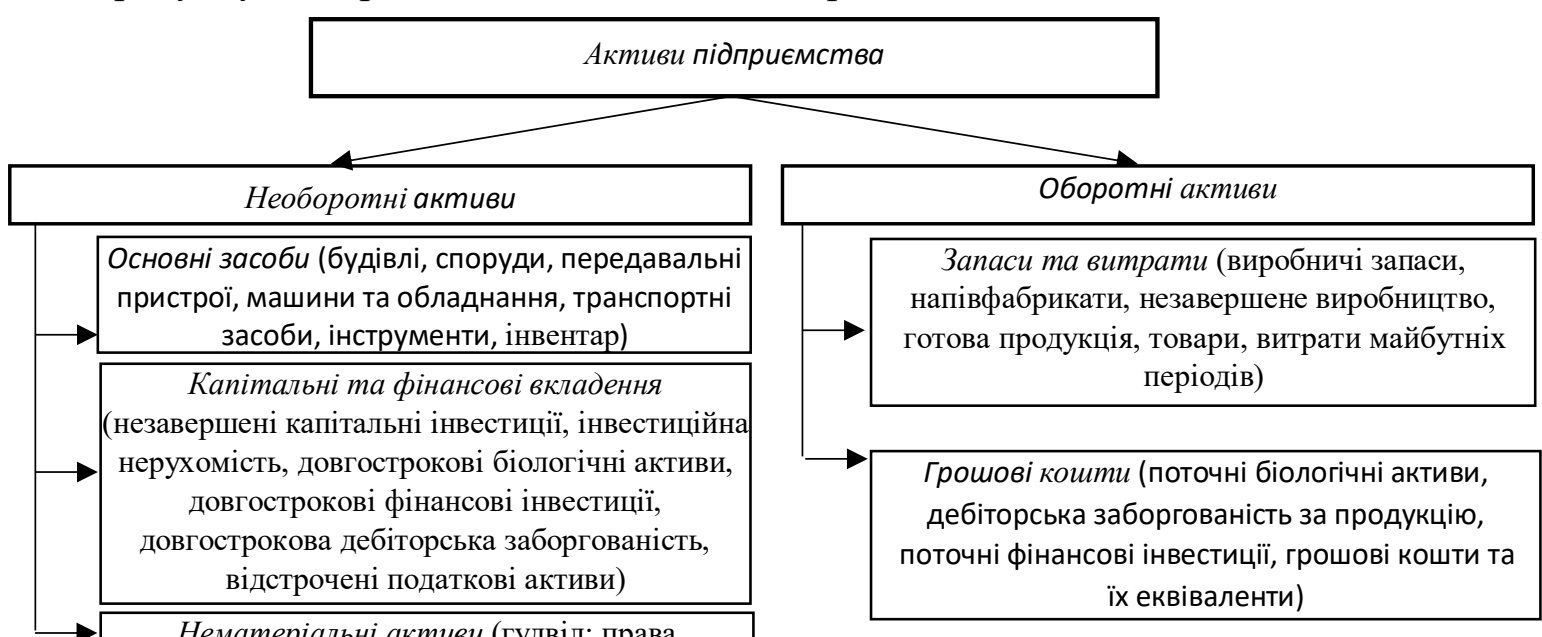

користування майном, природними ресурсами; права на знаки для товарів і послуг, на об'єкти промислової власності; авторські та суміжні 3 ними права; інші)

Рис. 1. Склад активів підприємства

Активи підприємства мають певні джерела походження (фінансування) - пасиви (капітал) [26, с. 485].

Джерелами формування активів підприємства виступають фінансові ресурси, які можна визначити, як сукупність грошових коштів (як у фондовій, так і у нефондовій формах), яку змогло зосередити у своєму розпорядженні підприємство на певний момент для здійснення своєї статутної діяльності шляхом вкладення цих коштів у активи підприємства для забезпечення розширеного відтворення та виконання фінансових зобов'язань [13, с. 110]. Такими джерелами можуть бути:

1) власні джерела (зареєстрований капітал, додатковий капітал, резервний капітал, нерозподілений прибуток підприємства);

2) позикові джерела (довгострокові та короткострокові кредити банків, кредиторська заборгованість).

Правильність формування та використання активів є важливою для забезпечення ефективності функціонування підприємства в цілому, оскільки визначає основні характеристики його фінансового стану, а зміни в управлінні цими процесами супроводжуються відповідними змінами фінансових характеристик [27].

Активи підприємства повинні відповідати функціональній направленості та обсягам діяльності виробничого підприємства [14]. Як зауважує Ковальчук Н.О., тільки при такій відповідності вони представляють для підприємства певну цінність, як иого економічні ресурси, що призначені для використання у наступному періоді [28]. При цьому їх використання повинно бути здійснене з урахуванням факторів часу, ризику та ліквідності, що забезпечить підприємству конкурентоспроможність на ринку [5, с. 121].

Таким чином, забезпеченість виробничого процесу необхідними активами в необхідній кількості та їх ефективне використання для нормального функціонування підприємства є важливою запорукою максимізації прибутку підприємства [4, с. 338].

3 метою забезпечення цілеспрямованого управління формуванням та 
використанням активів підприємств, необхідно систематизувати термінологію, що пов'язана з процесом класифікації іє досить широким полем для наукової діяльності [29, c. 235].

Задля узагальнення різних точок зору й підходів науковців до класифікації активів підприємства, систематизуємо їх різновиди за основними класифікаційними ознаками у таблиці 3. Спостерігаємо широке їх видове та змістовне різноманіття в економічній та фінансовій літературі. Ключовими критеріями класифікації активів підприємства є: економічний зміст; рівень ліквідності; місце використання; форма функціонування; характер фінансових джерел формування; характер участі в різних видах діяльності; терміни експлуатації; ризики залучення; ціна залучення; характер володіння тощо.

\section{Класифікація активів підприємства за основними ознаками*}

\begin{tabular}{|c|c|}
\hline $\begin{array}{l}\text { Класифікаційні } \\
\text { ознаки }\end{array}$ & Різновиди активів підприємства \\
\hline 1 & 2 \\
\hline \multirow{2}{*}{\begin{tabular}{|c|} 
За економічним \\
змістом (залежно \\
від строку та \\
специфіки \\
використання у \\
виробничій \\
діяльності \\
підприємства)
\end{tabular}} & $\begin{array}{l}\text { Необоротні (фіксовані) активи - це сукупність матеріально-фінансових ресурсів, що } \\
\text { використовуються в його господарській діяльності у своїй натуральній формі тривалий час } \\
\text { (більше року) і мають значну вартість окремого об’єкта, а також довгострокове відчуження майна } \\
\text { в підприємницьку діяльність інших суб’єктів господарювання (призначені для тривалого } \\
\text { використання в процесі фінансово-господарської діяльності). }\end{array}$ \\
\hline & $\begin{array}{l}\text { Оборотні (поточні) активи - грошові кошти та їх еквіваленти, що не обмежені у використанні, а } \\
\text { також інші активи, призначені для реалізації чи споживання протягом операційного циклу чи } \\
\text { протягом не більше дванадцяти місяців } 3 \text { дати балансу. }\end{array}$ \\
\hline \multirow{5}{*}{$\begin{array}{l}\text { За рівнем } \\
\text { ліквідності }\end{array}$} & $\begin{array}{l}\text { Першокласні високоліквідні активи, термін реалізації(трансформації) яких складає кілька днів без } \\
\text { втрати балансової вартості: грошові кошти; частина дебіторської заборгованості, оплата якої } \\
\text { відбудеться у семиденний строк; фонди підприємства, на якіє п підвищений попит з боку ринковоі } \\
\text { кон'юнктури. }\end{array}$ \\
\hline & $\begin{array}{l}\text { Високоліквідні активи, термін реалізації яких не перевищує один місяць, а реалізаційна ціна } \\
\text { складає менш ніж 90\% балансової вартості: дебіторська заборгованість, погашення якої } \\
\text { відбудеться у тридцяти денний строк; короткострокові фінансові інвестиції (цінні папери), } \\
\text { оборотні й інші фонди підприємства, які можуть бути реалізованими за вказаним строком без } \\
\text { значної втрати їх вартості. }\end{array}$ \\
\hline & $\begin{array}{l}\text { Середньоліквідні активи, термін реалізації яких складає до шести місяців, а втрата балансової } \\
\text { вартості не перевищує 50\%. До цієїгрупи належить майно підприємства, реалізація якого потребує } \\
\text { значного зниження ціни за умови існування помірного попиту з боку ринкової кон'юнктури, } \\
\text { морального та фізичного зносу в результаті їх експлуатації: транспортні засоби, машини и } \\
\text { устаткування, незавершене будівництво а ін. }\end{array}$ \\
\hline & $\begin{array}{l}\text { Низьколіквідні активи, які мають термін реалізації від шести до дванадцяти місяців, або втрата } \\
\text { балансової вартості яких складає від } 50 \text { до 90\%: майно підприємства, призначене для поточноі } \\
\text { господарської діяльності; транспортні засоби й устаткування, які для подовження їх експлуатаціі } \\
\text { потребують значних капітальних вкладень; комп’ютерна і оргтехніка та ін. }\end{array}$ \\
\hline & $\begin{array}{l}\text { Неліквідні активи, строк реалізації яких перевищує дванадцять місяців, або реалізаційна втрата } \\
\text { вартості становить більш ніж 90\%: фонди підприємства, на які практично відсутній попит з боку } \\
\text { ринкової кон'юнктури; майно, що підлягає списанню за ліквідаційною вартістю. }\end{array}$ \\
\hline \multirow{2}{*}{$\begin{array}{l}\text { Залежно від } \\
\text { місця } \\
\text { використання }\end{array}$} & $\begin{array}{l}\text { пься всередині підприємства (основні засоби, незавершені капітальні } \\
\text { тиви, готівка). }\end{array}$ \\
\hline & $\begin{array}{l}\text { Активи, щзо використовуються за межами підприємства (довгострокові фінансові вкладення, } \\
\text { дебіторська заборгованість, короткострокові фінансові вкладення). }\end{array}$ \\
\hline \multirow{4}{*}{$\begin{array}{c}\text { За формами } \\
\text { функціонування }\end{array}$} & $\begin{array}{l}\text { Матеріальні активи (характеризують активи підприємства, що мають матеріальну форму, } \\
\text { наприклад, основні засоби, незавершені капітальні вкладення, устаткування, виробничі запаси } \\
\text { сировини та матеріалів, запаси швидкозношуваних предметів, обсяг незавершеного виробництва). }\end{array}$ \\
\hline & $\begin{array}{l}\text { Нематеріальні активи (придбання підприємством прав користування окремими природними } \\
\text { ресурсами, майном; патентні права на використання винаходів, «ноу-хау»). }\end{array}$ \\
\hline & $\begin{array}{l}\text { Фінансові активи (грошові активи в національній та іноземній валюті, дебіторська заборгованість } \\
\text { у всіх її формах, коротко- та довгострокові фінансові вкладення). }\end{array}$ \\
\hline & Біоло \\
\hline \multirow{2}{*}{$\begin{array}{l}\text { За характером } \\
\text { фінансових } \\
\text { джерел } \\
\text { формування }\end{array}$} & $\begin{array}{l}\text { Валові активи (сукупність майнових цінностей (активів) підприємства, які сформовані за рахунок } \\
\text { як власного, так і позикового капіталу). }\end{array}$ \\
\hline & \begin{tabular}{|llll}
$\begin{array}{l}\text { Чисті активи (характеризують вартісну сукупність майнових цінностей підприємства, } \\
\text { сформованих винятково за рахунок його власного капіталу). }\end{array}$ & \\
\end{tabular} \\
\hline \multirow{2}{*}{$\begin{array}{c}\text { За характером } \\
\text { участі в різних } \\
\text { видах діяльності }\end{array}$} & $\begin{array}{l}\text { ні засоби; нематеріальні активи, що обслуговують операційний процес; } \\
\text { и). }\end{array}$ \\
\hline & $\begin{array}{l}\text { Iнвестиційні активи (незавершені капітальні вкладення; довгострокові та короткострокові } \\
\text { вкладення; обладнання, призначене до монтажу). }\end{array}$ \\
\hline
\end{tabular}




\begin{tabular}{|c|c|}
\hline & \\
\hline 1 & 2 \\
\hline \multirow{3}{*}{$\begin{array}{l}\text { За характером } \\
\text { володіння }\end{array}$} & Власні активи. \\
\hline & Орендовані (лізингові) активи. \\
\hline & Безоплатно отримані активи. \\
\hline \multirow{2}{*}{$\begin{array}{l}\text { За термінами } \\
\text { експлуатації }\end{array}$} & $\begin{array}{l}\text { Короткострокові активи - це активи призначені для використання або продажу на протязі всього } \\
\text { операційного циклу, або дванадцяти місяців від звітної дати. Короткострокові активи представлені } \\
\text { в грошових формах або їх еквіваленті, які можуть використовуватися без обмежень. }\end{array}$ \\
\hline & $\begin{array}{l}\text { Довгострокові активи - це активи, які утримуються на балансі більше одного операційного циклу } \\
\text { i не можуть бути швидко конвертовані в грошову форму. }\end{array}$ \\
\hline \multirow{5}{*}{$\begin{array}{l}\text { За ризиком } \\
\text { залучення }\end{array}$} & Безризикові активи (застосування яких не змінює ступінь ризику діяльності). \\
\hline & $\begin{array}{l}\text { Активи з низьким рівнем ризику (від використання яких зростає ризик, що не здійснює суттєвого } \\
\text { впливу на результати роботи підприємства). }\end{array}$ \\
\hline & $\begin{array}{l}\text { Активи з нормальним рівнем ризику (мають ризик, проте підприємство здатне подолати його вплив } \\
\text { в межах існуючих систем управління). }\end{array}$ \\
\hline & Активи з високим рівнем ризику (потребують додаткових заходів страхування ризику). \\
\hline & Активи з критичним ризиком (використання яких призводить до втрат). \\
\hline \multirow{5}{*}{$\begin{array}{l}\text { За цінами } \\
\text { залучення }\end{array}$} & $\begin{array}{l}\text { Оптимальні активи (підвищують ефекти від експлуатації активів, забезпечують розширення } \\
\text { виробництва та прибутковості підприємства). }\end{array}$ \\
\hline & $\begin{array}{l}\text { Ефективні активи (не приносять прямого ефекту від додаткового залучення активів, проте } \\
\text { підвищують ефекти та ефективність експлуатації вже наявних активів, часто виступаючи } \\
\text { каталізаторами ефективного управління). }\end{array}$ \\
\hline & $\begin{array}{l}\text { Нейтральні активи (забезпечують можливість експлуатувати наявні активи з попереднім рівнем } \\
\text { ефективності, але без залучення яких підприємство неспроможне продовжити господарську } \\
\text { діяльність). }\end{array}$ \\
\hline & $\begin{array}{l}\text { Регресивні активи (дають можливість в короткотерміновому періоді підтримати забезпечення } \\
\text { активами, без яких функціонування підприємства неможливе, проте в перспективі призводить до } \\
\text { зниження ефектів та господарських втрат). }\end{array}$ \\
\hline & $\begin{array}{l}\text { Критичні активи (забезпечують підтримання господарських операцій, проте за заміни ринкової } \\
\text { кон’юнктури призводять до банкрутства підприємства). }\end{array}$ \\
\hline
\end{tabular}

Висновки. Отже, проведене дослідження дозволило удосконалити підходи до трактування категорії «активи підприємства», з'ясувати їх сутнісні характеристики та ключові властивості, склад та видове різноманіття.

\section{Список використаних джерел:}

1.Жук О.С. Оцінка стану та структури активів підприємства. Наукові записки Національного університету «Острозька академія». Серія «Економіка». 2016. Вип. 3(31). С. 16-20.

2.Каціман С.О., Шаманська О.І. Вдосконалення системи управління активами підприємства. Глобальні та національні проблеми економіки. 2017. Вип. 20. С. 357-361.

3.Рєпіна I.М. Активи підприємства: категоріальний аналіз та систематологія. Формування ринкової економіки: зб. наук. nраць / М-во освіти і науки України, ДВНЗ «Київ. нац. екон. ун-т ім. Вадима Гетьмана»; редкол.: А.Ф. Павленко (відп. ред.) та ін. Київ: КНЕУ, 2008. Спец. вип.: Економіка підприємства: теорія і практика : в 2 ч. Ч. II. С. 548-553. URL: http://ir.kneu.edu.ua/bitstream/2010/22404/1/548-553.pdf (дата звернення 15.04.2019).

4.Скоробогатова В.В. Сутність категорії «активи»: аналіз наукових джерел. Проблеми теорї та методологіі бухгалтерського обліку, контролю і аналізу. 2011. № 3 (21). Ч. 2. С. 338-348.

5.Петруня Н.В. Концептуальні підходи до визначення сутності активів підприємств. Облік $і$ фінанси АПК. 2011. № 1. C. 120-124. URL: http://magazine.faaf.org.ua/konceptualni-pidhodi-do-viznachennya-sutnosti-aktiviv-pidpriemstv.html (дата звернення 15.04.2019).

6.Музичка O.C. Сутність управління оборотними активами підприємства. URL: http://repository.vsau.org/getfile.php/2722.pdf (дата звернення 15.04.2019).

7.Сердюков К.Г., Андруха К.С. Управління активами та пасивами підприємства в сучасних умовах. URL: http://dspace.khif.edu.ua/bitstream/handle/123456789/148/Управління\%20активами\%20та\%20пасивами\%20підприємств a\%20в\%20сучасних\%20умовах.pdf?sequence=1\&isAllowed=y (дата звернення 15.04.2019).

8.Поліщук М.П., Михайленко П.П. Основи підприємницької діяльності. Житомир: ЖITI, 2000. 172 с. URL: https://buklib.net/books/26834/ (дата звернення 15.04.2019).

9.Оцінка активів підприємства: навчальний посібник / Ю.В. Панасовський, Б.А. Семененко, О.М. Теліженко та ін.; за заг.ред. Ю.В. Панасовського. Суми: Університетська книга, 2009. 512 с.

10. Олійник Т.О., Мірошниченко О.В. Основні напрями підвищення ефективності управління активами. Інвестиції: практика та досвід. 2014. № 21. С. 73-77.

11. Ковальов В.В. Фінансовий менеджмент: підручник. Москва: Велбі. 2011. 304 с.

12. Бланк И.А. Управление активами. Київ: Ника-Центр, Эльга, 2002. 720 с.

13. Іванчук Н.В. Формування активів підприємства. Наукові записки. Серія «Економіка». 2008. Вип. 10. Ч. 2. С. 109121.

14. Лисевич С.Г. Оцінка стану активів підприємства та управління ними. URL: https://www.pdaa.edu.ua/sites/default/files/nppdaa/6.2/206.pdf (дата звернення 15.04.2019). 
16. Шелудько B.M. Фінансовий менеджмент : підручник. 2-ге вид., стер. Kиїв, 2013.375 с. URL: https://pidruchniki.com/20080215/finansi/aktivi_pidpriyemstva (дата звернення 15.04.2019).

17. Стоянова О.Г. Методологічні основи управління оборотними активами підприємства. Інвестиціï: практика та досвід. 2014. № 7. с. 7-16.

18. Константюк H., Когут I. Основні аспекти управління активами підприємства. URL: http://elartu.tntu.edu.ua/bitstream/123456789/18073/2/ConfFMNES_2016_Konstantiuk_N-Key_aspects_of_enterprise_8587.pdf (дата звернення 15.04.2019).

19. Соколов Я.В. Актив: это очень сложно. Бухгалтерскийучт-веселая наука: сборник статеи. Москва: ООО «1СПаблишинг», 2011, $638 \mathrm{c}$.

20. Мних Є.В. Економічний аналіз: підручник.

https://pidruchniki.com/1663111641846/ekonomika/ekonomichniy_analiz (дата звернення 15.04.2019).

21. Колодяжна К.С. Управління оборотними коштами торговельних підприємств в сучасних умовах. Актуальнi проблеми економіки. 2015. № 19. С. 89-96.

22. Патров В.В., Ковалёв В.В. Как читать баланс. Москва: Финансы и статистика, 1991. 128 с.

23. Загальні вимоги до фінансової звітності: Національне положення (стандарт) бухгалтерського обліку 1. URL: http://zakon5.rada.gov.ua/laws/ show/z0336-13 (дата звернення 15.04.2019).

24. Про затвердження Національного положення (стандарту) бухгалтерського обліку «Загальні вимоги до фінансової звітності»: наказ Міністерства фінансів України / Кабінет Mіністрів України. URL: https://zakon.rada.gov.ua/laws/show/z0336-13 (дата звернення 15.04.2019).

25. Савицька О.В. Аналіз активів підприємства. Аналіз господарськоїдіяльності підприємства. 2006. С. $438-441$.

26. Чемчикаленко P.A., Майборода О.Є., Люткіна А.В. Оцінка ефективності управління активами та пасивами підприємства. Економіка $i$ суспільство. $2017 . \quad$ Вип. №11. C. 485-489. http://www.economyandsociety.in.ua/journal/11_ukr/78.pdf (дата звернення 15.04.2019).

27. Константюк H., Когут I. Основні аспекти управління активами підприємства. URL: http://elartu.tntu.edu.ua/bitstream/123456789/18073/2/ConfFMNES_2016_Konstantiuk_N-Key_aspects_of_enterprise_8587.pdf (дата звернення 15.04.2019).

28. Ковальчук H.O. Особливості управління оборотними активами на вітчизняних підприємствах. URL: http://www.nbuv.gov.ua/portal/soc_gum/Nvbdfa/2011_1/kovalch.pdf (дата звернення 15.04.2019).

29. Петруня Н.В. Класифікація активів підприємств з урахуванням міжнародних стандартів фінансової звітності // Збірник наукових праць Національного університету державної податкової служби України, № 1, 2010. - c. 235-242. URL: http://lib.osau.edu.ua/jspui/bitstream/123456789/1339/1/28_2010_Smyrnova.pdf (дата звернення 15.04.2019).

30. Шифріна Н.I. Класифікація активів підприємства за рівнем ліквідності. Вісник економіки транспорту $i$ промисловості. 2011. № 34. С. 348-350.

Рецензент д.е.н., професор Вахович I.M.

УДК 658.15:621

Мажаренко К.П., старший викладач

Бражнікова Т.М., студентка

Кременчуцький національний університет ім. М.Остроградського

\section{ВИЗНАЧЕННЯ МЕХАНІЗМУ АНТИКРИЗОВОГО УПРАВЛІННЯ НА ВІТЧИЗНЯНИХ ПІДПРСМСТВАХ МАШИНОБУДІВНОЇ ГАЛУЗІ}

У статті розглядаються проблеми, які впливають на ефективність організаційно-економічного механізму антикризового управління підприємствами машинобудівного комплексу. Проводиться оцінка основних показників діяльності вітчизняного машинобудування. Авторами сформовано концепцію моделі організаційно-економічного механізму антикризового управління для підприємств даної галузі.

Ключові слова: антикризове управління, криза, діагностика, контролінг, підприємства машинобудування.

Mazharenko K., Brazhnikova T.

\section{DETERMINATION OF MECHANISM OF CRISIS-PROOF MANAGEMENT IN DOMESTIC ENTERPRISES OF MACHINE-BUILDING INDUSTRY}

The article considers problems influencing effectiveness of organizational/economic mechanism of crisisproof management in enterprises of machine-building industry. The assessment of the main indicators of domestic engineering enterprises is carried out. The conception of organizational/economic mechanism of crisis-proof management was determined for enterprises by the authors. 